DOI : https://doi.org/10.31539/leea.v4i1.1369

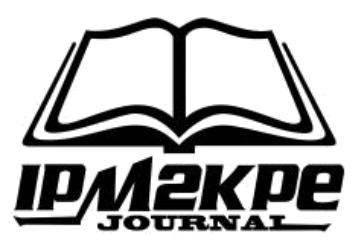

\title{
THE COOPERATIVE PRINCIPLE ANALYSIS IN ABOUT TIME MOVIE
}

\author{
Yenny Widya Sari ${ }^{1}$ \\ Universitas Putera Batam (UPB), Indonesia \\ Afriana $^{2}$ \\ Universitas Putera Batam (UPB), Indonesia \\ pb161210096@upbatam.ac.id ${ }^{1}$
}

Submit, 04-07-2020 Accepted, 20-07-2020 Publish, 24-07-2020

\begin{abstract}
This research had aimed to analyze cooperative principle by observing the characters' utterances in About Time movie. A descriptive qualitative method was used in analyzing the data because it would be explained by words, phrases, and sentences. The data would be based on the characters' utterances in About Time movie. In collecting the data, the researcher used the observational method and non-participatory, note-taking techniques. Pragmatic identity method was applied in analyzing the data. The result findings showed that all four maxims in cooperative principle were found through the utterances in About Time movie. The researcher found 37 data of maxims. The result indicated that there were 14 (38\%) data maxim of quantity, 14 (38\%) data maxim of relation, 7 (19\%) data maxim of quality and $2(5 \%)$ data maxim of manner. In summary, the most frequently data were found in the maxim of quantity and maxim of relation. The least data were found in maxim of manner.
\end{abstract}

Keywords: Cooperative Principle, Maxims, Utterances, Movie

\section{INTRODUCTION}

Language is used as a tool for communication between people. Language is usually used to express people's thoughts, ideas, and information that needed to be shared, especially in conversation. Therefore, in order to make these thoughts, ideas and information are well presented, people need to understand the intention of those messages. However, a good conversation is not only about to understand the intention that is being said by the speaker but also there are some feedbacks that are given by the interlocutors. According to Karim (2016), successful conversation is achieved when both of the participants are cooperative with each other. It can be concluded that a good conversation is started with a cooperative conversation that makes the conversation is acceptable. 
The study that discussed cooperative conversation is called a cooperative principle that was supported by Grice (1975) theory. According to Grice (1975) cooperative principle is the term in conversation by giving the information such as is required for both speaker and hearer. The contribution of this conversation has four maxims; maxim of quantity, maxim of quality, maxim of relation and maxim of manner. This science closely related to the phenomenon of human daily life. Besides in the daily conversation that found in the society, a cooperative conversation is also showed in various media such as movie, talk show, debate and even in literary works such as novel, short story and etc.

The phenomenon example of this cooperative principle could be found in the conversation of the movie. The movie is the representative of human life that is being shown through the media. This research investigated four maxims in cooperative principle that could be found in movie entitled 'About Time'. About Time is a fantasy/romance movie that was released in 2013. This movie was directed by Richard Curtis. This movie tells about a man named Tim who has the capability to do time travel. He uses this capability to find a girlfriend, then he met a girl named Marry.

There were several previous researches that discussed cooperative principle. Yusro, et.al (2020), the finding data were not only about maxims, but there were violations of maxims in the EFL classroom interaction. Laila (2020). the result showed that there were two maxims that violated by the candidates, maxim of relation and maxim of manner. Other than that, the most frequent data were found in maxim of quality by Indonesian Presidential Debate candidates. State \& Adebola (2018) the finding data revealed that the use of cooperative principles in Whatsapp is high to the extent between speaker and interlocutor. The result denoted that the most frequent data located in the maxim of relation and maxim of manner.

Ngenget (2017), the result of this research showed that the four maxims of Gricean were applied in Manado and Malay language in order to give the information that in accordance with the cooperative principles. Karim (2016) the result analysis in this research showed that the receptionist at the front desk carefully noticed both cooperative principle (CP) and politeness principle (PP), however, the guests' responses were not complied with those principles. Thakur (2016) research showed the result that the cooperative principle values are not located in the observing, yet it is located in flouting as the result that literary artists are able to produce several satisfying devices.

$\mathrm{Li}$ (2015) identified the result that the significance of English learning getting to be more self-evident because of the application of the cooperative principle in oral conversation. Retnowaty (2013) research showed 688 data of observance of maxims and 142 data of non-observance of maxims. The most frequent data appeared in the maxim of relation because the participants gave the relative answers. Herawati (2013) research showed that there was four fulfillment 
of maxims from 100 conversations. Maxim of quantity 33 data (33\%), maxim of quality 100 data (100\%), maxim of relation 90 data $(90 \%)$ and maxim of manner 45 data (45\%). Pan (2012) research showed the correlation between cooperative principle and humor that were used in Grice's cooperative principle theory.

From these previous researches, it can be summarized that the cooperative principle can be found in various fields because the conversation is always used in human daily life. The advantage of this research is that people can learn new information about cooperative conversation through different data source. In order to conduct further analysis about cooperative principle, the researcher uses different data source from the movie that can prove the cooperative principle appears in various aspects. Having different data source will make a new perspective about cooperative conversation in communication. Through the characters' utterances, people can see how important the use of the cooperative principle in the conversation is.

\section{LITERATURE REVIEW}

In order to make the conversation is successful between the speaker and the interlocutor, people need to comply with the rules of the cooperative principle. The cooperative principle was found by Grice. According to Grice (1975) the cooperative principle is to make your conversational contribution such as is required, at the stage at which it occurs, by the accepted purpose or direction of the talk exchange in which you are engaged. Grice stated (Megah \& Wahyuni, 2018) both the speaker and interlocutor intend to be cooperative when they have conversation so that it will not make ambiguous responses. The cooperative principles consist of four maxims; maxim of quantity, maxim of quality, maxim of relation and maxim of manner. In each of this maxim has its own role in making the conversation cooperative as it is required which will be explained below;

\section{Maxim of Quantity}

Grice stated (Yule, 1996) maxim of quantity is make your contribution in the conversation as informative as is required. It means that when someone asked about something, the hearer must answer as the informative answer, say enough, and don't say too much. It must be the answer or information that is needed by the person who asked the question. Even though giving more information sometimes will be useful, but in cooperative principle rules only need the information that is needed.

For example:

Mandy : "Hei, what is the capital city of Canada?"

Austin : "It is Ottawa.",

From this conversation between Mandy and Austin showed that this is one of examples maxim of quantity because Austin gave the information about the capital city of Canada is Ottawa as it is required. 


\section{Maxim of Quality}

People like true answers. Maxim of quality is about saying something that you have the reason to believe is true. The rule is don't give any information that might be false because it will be flouting the maxim. The interlocutor must say something that is true or something that she/he sure about the answer.

For example:

Ali : "When is physics exam?"

Jordan : "This Saturday"

In the conversation above showed the phenomena of a maxim of quality. The answer that was given by Jordan is in accordance with the rule in maxim of quality. Jordan answered with the truth that he believed is true.

\section{Maxim of Relation}

Maxim of relation is one of the maxims that often found in the conversation. Sometimes, people answer with the relevant answer and sometimes they are not. According to Grice (as cited in Yule, 1996) the rule in maxim of relation is saying something only what is relevant to the questions. Megah \& Wahyuni (2018) stated that maxim of relation is staying on the topics that were being talked about and don't stray from the topics.

For example:

$\begin{array}{ll}\text { Rara } & \text { : 'Hei, do you like K-pop music?", } \\ \text { Astra } & \text { :'Of course I do", } \\ \text { Rara } & \text { : 'Who is your favorite group?', } \\ \text { Astra } & \text { : 'Blackpink, how about you?', } \\ \text { Rara } & \text { : 'Ahh I like blackpink too, but I like BTS more", }\end{array}$

The conversation between Rara and Astra is an example of maxim of relation. It could be seen that the question and the answer are relevant to each other.

\section{Maxim of Manner}

Maxim of manner when the conversation is be brief, clear, and unambiguous. According to Grice ( as cited in Yule, 1996) these are the rules in maxim of manner;
a. Avoid obscurity of expression
b. Avoid ambiguity
c. Be brief (avoid unnecessary prolixity)
d. Be orderly

For example:

Qara : "What are the ingredients in the making of milkshake?"

Anna : "A cup of milk, a cup of ice cream and whipped cream"

The example above showed maxim of manner because Anna gave perspicuous answer with brief, clear, orderly and unambiguous explanation. 
These four maxims have their own rules in making the conversation stay efficient. The cooperative conversation will make both of the speaker and interlocutor connect to each other. However, if the interlocutor is not obeying the rules, it would break or violet the maxims.

\section{RESEARCH METHOD}

This research was conducted with a descriptive qualitative method. The object of the research was maxims in cooperative principle. The observational method and non-participatory technique were applied in collecting the data. The researcher observed the utterances by the characters in the movie and then collected the data by using the note-taking technique. The researcher used the non-participatory technique because the researcher didn't involve directly as the participants who had a conversation in the movie. The pragmatics identity method was applied in the analysis of the data.

\section{FINDINGS}

The researcher has found 37 data of cooperative principle from characters' utterances in About Time Movie. This research used Grice's theory in cooperative principle to analyze the utterances that were being spoken by the characters in About Time movie. The result showed that the most frequent data were in maxim of quantity and maxim of relation with each had 14 data. The least data were in maxim of manner with 2 data. The finding results were presented in the table below;

Table 1. Cooperative Principles found in About Time Movie

\begin{tabular}{llll}
\hline No & Cooperative Principles & Frequency & Percentage \\
\hline 1. & Maxim of Quantity & 14 Data & $38 \%$ \\
\hline 2. & Maxim of Quality & 7 Data & $19 \%$ \\
\hline 3. & Maxim of Relation & 14 Data & $38 \%$ \\
\hline 4. & Maxim of Manner & 2 Data & $5 \%$ \\
\hline & TOTAL & 37 Data & \\
\hline
\end{tabular}

\section{Data 1}

Tim : 'So, you're saying that you and granddad, and his brother could all travel back in time?",

Dad : "Absolutely."

Tim : "And you still do?"

Dad : "Absolutely."

(00:05:38) 
The first data showed in the conversation between the main characters named Tim and his dad. In this conversation, when Tim asked about something that were explained before by his dad and his dad answered it with the information as it is required. This phenomenon above included in maxim of quantity because the answer was given by the interlocutor without any further information than is required.

\section{Data 2}

Tim : ' If it's true, which it isn't. Although it is, it isn't obviously. But if it was, which it isn't..."

Dad : "Which it is",

Tim : "'But if it was, how would I?

Dad : ' 'How? Is the easy bit, in fact you go into a dark place, big cupboard are very useful generally. Toilets at a pinch then you clench your fist like this. Think of the moment, you're going to and you'll find yourself there." (00:05:55)

The researcher found two maxims in this conversation between Tim and his dad. The first maxim was maxim of quality which the utterance was given by Tim's dad. Dad gave an explanation to Tim about the time travel and tried to convince Tim because Tim didn't believe what his dad was talking about. However, Tim's dad responded confidently with the sentence "which it is" because he believed this magic was true. Through this explanation, it could be said that Tim's dad utterance included in maxim of quality, say what is believed as true information.

Besides maxim of quality, the researcher also found maxim of manner in Tim's dad response. When Tim asked his dad how would he do time travel, his dad answered with clear information about the way Tim's could do time travel and there is no ambiguity in the answer.

\section{Data 3}

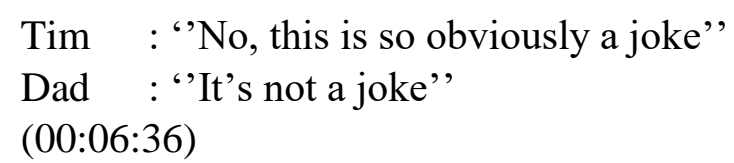

In the third data, the conversation still occurred between Tim and Dad. The researcher investigated that Dad's response from Tim's utterance as maxim of quality. Even though Tim still didn't believe that he could time travel, but his dad still tried to answer truthfully. He was sure of what he said. 


\section{Data 4}

Ace : 'You all right, Tim?"

Tim : "Yes, yeah, good, Ace",

Ace : 'Good, come on. It's nearly midnight and we've got to find"'

(00:06:36)

The utterances that happened between Ace and Tim happened when they were at the New Year Eve's party. Ace saw Tim with a confused face, then Ace asked Tim if he was all right, Tim answered relevantly with the word good. From this explanation, it could be said that this conversation included in maxim of relation because there was a correlation between the question and the answer.

\section{Data 5}

Polly : 'Thank You, Tim"

Tim : 'You're welcome, Polly"

(00:08:35)

In this conversation, there were Polly and Tim who just kissed at New Year Eve's party. Tim kissed Polly and then Polly said thank you for kissing her. The answer that Tim gave to her was relevant to Polly's utterance. In this data, the researcher classified this conversation as maxim of relation.

\section{Data 6}

Tim : "What happened to Uncle Fred?"

Dad : "Absolutely sod all, wasted his life",

(00:09:46)

The situation in this conversation was when Tim asked his dad about what happened to his Uncle when he could do time travel, then Dad responded with the required information. He said that Uncle Fred wasted his life. These utterances showed that the conversation between Tim and Dad above included cooperative conversation in maxim of quantity. It was classified as maxim of quantity because Tim's dad gave the information as it is required and there is no further explanation.

\section{Data 7}

Dad : 'You have to use it for things that you really think will make your life the way you want it to be. Come on, really think about this.',

Tim : ' Well, to be honest, I suppose at the moment, it would be just great if it could help me get a girlfriend.

(00:09:50)

This conversation above included in maxim of relation. The situation that happened in this conversation was when Tim already believed about time travel. His dad suggested him to do something that Tim wanted to do, Tim responded that he wanted to get a girlfriend. From this explanation, it could be said that 
Tim's answer was relevant to his dad's utterance. Their utterances also showed that the conversation followed the rule of cooperative principle in maxim of relation.

\section{Data 8}

Dad : "Have you enjoyed having Charlotte here all summer, Tim?"

Tim : "Yeah"

(00:13:04)

In the eighth data, it showed that maxim of quantity occurred in this conversation. Maxim of quantity requires both speaker and interlocutor contribution as informative as it is required. It could be seen in the conversation when Tim's dad asked his son about Charlotte, then Tim answered with the utterance "'Yeah', Tim gave an answer that as it is required from Dad's question and he also didn't say too much.

\section{Data 9}

A man : :"What do you think of show?"

A woman : "I thought it was incredible",

(00:31:34)

There was relevancy in this conversation between a man and a woman. In this scene, it didn't show the main character, but there was scene of strangers in bar who watched playwright. When the man asked the woman about the playwright, the woman answered immediately with informative answer as it is required from the question. This conversation could be said cooperative conversation because both the speaker and the interlocutor obeyed the rule of cooperative principle.

\section{Data 10}

Kit Kat: 'I've only just noticed this cat in this picture. See that cat?'

Tim : 'I do see that cat', '’My God! My god!'

Kit Kat: "What?",

Tim : "It's her",

(00:34:17)

Through this conversation between Kit Kat and Tim at the art gallery, the researcher classified this conversation as cooperative conversation. There were two maxims in their utterances. They were maxim of relation and maxim of quality. Maxim of relation occurred in Tim's answer when Kit Kat asked him that did he see the cat in that picture, then Tim answered with 'I do see that cat'. Tim's response proved that their conversation was relevant to each other. Meanwhile, maxim of quality occurred when Tim responded Kit Kat's question with 'it's her'. He answered with confidence because he believed the girl that he saw at the art gallery was the girl that he was looking for. As already explained, 
the rule in maxim of quality is not to say something that is believed to be false. Yet, Tim believed the girl was true.

\section{DISCUSSION}

In the finding result showed that all four maxims were found in About Time movie by Richard Curtis. These four maxims based on cooperative principle theory that was supported by Grice (1975). The researcher found the data from characters' utterances in About Time movie. All four maxims were applied to this analysis.

From the finding data, the most dominant data were found in maxim of quantity and maxim of relation. Grice stated as cited in Retnowaty (2013), there are two rules to contribute to the maxim of quantity. First, make your conversation as informative as is required for the exchange of current purpose. Second, don't make your conversation more informative than is required. These rules could be shown from the finding data of maxim of quantity from the characters' utterances in About Time Movie. Tim said 'so, you're saying that you and granddad, and his brother could all travel back in time?'" then the interlocutor answered 'absolutely". The phenomenon between characters' utterances showed that the information that had given by Tim's dad was an informative answer. There was no additional information in this conversation.

The other dominant data were found in maxim of relation. In Grice (1975) theory, the rule in this cooperative is to make your conversation relevant. It means that the speaker and interlocutor need relevancy between the question and the answer. This phenomenon could be found in the conversation between Tim and Polly. When Polly uttered "Thank You, Tim", then Tim answered 'you are welcome, Polly". This conversation contained maxim of relation because there was relevancy between the utterances "'thank you'" and 'you are welcome', This maxim became one of the most dominant data in About Time movie because mostly the conversations in About Time movie were related to each other.

Meanwhile, the least data were found in maxim of manner. In the maxim of manner, the researcher found 2 data. According to Grice (1975) theory, a maxim of manner has the rules to avoid obscurity, avoid ambiguity, be brief, and be orderly. In About Time movie, the researcher could not find much data that had these rules because of most of the conversation contained required and relevant information. The phenomenon of a maxim of manner could be shown in the conversation between Tim and his dad. When Tim asked about how could he do time travel, Tim's dad answered with clear information and there was no ambiguity in his answer.

The discussion above indicated that all four maxims in cooperative principle were found through the characters' utterances in About Time movie. Simply, the theory was applied in these utterances. The conversation between the characters could be said as a cooperative conversation because it followed the rules of a cooperative principle. The most frequent data in this movie showed that 
the characters' utterances gave more required and relevant information than the other two maxims.

\section{CONCLUSION}

From the analysis above it could be concluded that the cooperative principle occurred in About Time movie. It consisted of four maxims that were analyzed by the characters' utterances. Based on analysis data in About Time movie, the researcher found that the most frequent data were in maxim of quantity $(38 \%)$ and maxim of quality (38\%). It showed that the characters were having a conversation by giving information as it required and relevant answer. Meanwhile, the researcher found the least data were in maxim of manner (5\%).

\section{REFERENCES}

Grice, H. P. (1975). Logic and Conversation, in P. Cole and J. Morgan (eds), Syntax and Semantic, 3: Speech Acts. Academic Press.

Herawati, A. (2013). The Cooperative Principle: is Grice's Theory Suitable to Indonesian Language Culture? Jurnal Lingua Cultura, 7(45), 43-48.

Karim, S., A. (2016). Analysis on Cooperative Principle and Politeness Principle in Guest Complaining at $\mathrm{x}$ Hotel in Kuta-Bali. RETORIKA: Jurnal Ilmu Bahasa, 2(2), 394-408. https://doi.org/10.22225/jr.2.2.409.394408.ANALYSIS

Laila, N., A. (2020). Cooperative Principles in the 2019 Indonesian Presidential Debate : Grice' s Maxims Analysis. Applied Linguistics Research Journal, 4(1), 14-22. https://doi.org/10.14744/alrj.2019.85057

Li, Q. (2015). The Application of Cooperative Principle in Oral English Learning. International Journal on Studies in English Language and Literature, 3(1), 39-48.

Megah, S., I., \& Wahyuni, K., D. (2018). An Analysis of the Cooperative Maxims in the Omar" Movie. Cahaya Pendidikan, 4(1), 70-78. https://doi.org/http://dx.doi.org/10.33373/chypend.v4i1.1283

Ngenget, S. (2017). A Revisit of the Gricean Maxims in Manado Malay Language. Script Journal: Journal of Linguistics and English Teaching, 2(2), 203-212.

Pan, W. (2012). Linguistic Basis of Humor In Uses of Grice' s Cooperative Principle. International Journal of Applied Linguistics and English Literature, 1(6), 20-25. https://doi.org/10.7575/ijalel.v.1n.6p.20

Retnowaty. (2013). The Awareness and Realization of Grice's Cooperative Principles in the Conversations Among Non-native English. English Education Journal, 3(2), 68-77.

State, O., \& Adebola, O. A. (2018). Cooperative Principle Maxims In Whatsapp Conversations Among Undergraduates in the Federal University of Technology. Advances in Social Sciences Research Journal, 5(10), 542557. 
Thakur, V., S. (2016). Cooperative Principle of Conversations in Vikram Seth's a Suitable Boy: A Socio-pragmatic Assesment of Inferential. International Journal of Education, 9(1), 24-31.

Yule, G. (1996). Pragmatics (illustrate). Oxford University Press.

Yusro, A., Sutopo, D., \& Yuliasri, I. (2020). The Application of Cooperative Principles in EFL Classroom Interaction: The Case of SMAN 4 Pekalongan. English Education Journal, 10(2), 124-130. 